\title{
Sustainable Valorization of Olive Pomace Waste to Renewable Biofuels, Biomaterials and Biochemicals Via Pyrolysis Process: Experimental and Numerical Investigation
}

Mohamed Hechmi Aissaoui ( $\square$ amohamedheshmi@gmail.com )

Universite de Tunis El Manar Faculte des Sciences de Tunis https://orcid.org/0000-0003-0069-5634

Aïda Ben Hassen Trabelsi

Centre de Recherches et Technologies de l'Energie

Gmar Bensidhom

Centre de Recherches et Technologies de l'Energie

Selim Ceylan

Ondokuz May?s Üniversitesi: Ondokuz Mayis Universitesi

James.J Leahy

University of Limerick

Witold Kwapinski

University of Limerick

\section{Research Article}

Keywords: Pyrolysis, olive pomace wastes, DAEM model, kinetics, biofuels, biofertilizers

Posted Date: September 29th, 2021

DOI: https://doi.org/10.21203/rs.3.rs-831293/v1

License: (c) (i) This work is licensed under a Creative Commons Attribution 4.0 International License.

Read Full License 
1 Sustainable valorization of olive pomace waste to renewable biofuels, biomaterials and

2 biochemicals via pyrolysis process: experimental and numerical investigation

3

4 Mohamed Hechmi Aissaoui ${ }^{1,2}$, Aïda Ben Hassen Trabelsi ${ }^{1}$, Gmar Bensidhom ${ }^{1}$, Selim Ceylan ${ }^{3}$,

$5 \quad$ James J Leahy ${ }^{4}$; Witold Kwapinski ${ }^{4}$

$6{ }^{1}$ Research and Technology Centre of Energy, Technopôle Borj-Cédria, B.P Nº95, 2050, Hammam-

7 Lif, Tunisia.

$8 \quad{ }^{2}$ Faculty of Sciences of Tunis, Tunis El Manar University, Campus Universitaire El-Manar, 2092,

9 El Manar, Tunisia.

$10{ }^{3}$ Ondokuz Mayıs University, Faculty of Engineering, Chemical Engineering Department, 55139,

11 Kurupelit, Samsun, Turkey.

$12{ }^{4}$ Department of Chemical Sciences, University of Limerick, Bernal Institute, V94 T9PX Limerick,

13 Ireland.

14 Corresponding author: amohamedheshmi@gmail.com

\section{Highlights:}

$>$ Slow pyrolysis of OPW was conducted using a fixed-bed reactor and a TGA apparatus

The released permanent gases show an interesting LHV up to $11 \mathrm{MJ} / \mathrm{Kg}$

$>$ The biochar characterestics and composition emphazeise its use as fertilizer

$>$ The activation energy $(\mathrm{Ea})$ ranged from 121.6 to $151.6 \mathrm{~kJ} / \mathrm{mol}$ 


\section{Abstract}

26 This work demonstrates, experimentally and numerically, the potential of Olive Pomace Waste

27 (OPW) to produce renewable biofuels (pyrolytic oil and gas), bio-chemicals (tars as source of

28 bioactive molecules) and bio-fertilizers (chars) through slow pyrolysis. Experimental pyrolysis

29 runs were conducted at 500,600 and $700{ }^{\circ} \mathrm{C}$ as final pyrolysis temperature, 15,20 and $25^{\circ} \mathrm{C} / \mathrm{min}$

30 as heating rate and $1 \mathrm{~h}$ as residence time, in a fixed bed pyrolyzer. In the optimum pyrolysis

31 conditions $\left(600^{\circ} \mathrm{C}\right.$ and $\left.15^{\circ} \mathrm{C} / \mathrm{min}\right), 33 \mathrm{wt} . \%$ of oil, $30.00 \mathrm{wt} . \%$ of char and $37 \mathrm{wt} . \%$ of gas were

32 produced. Recovered pyrolytic oil presents good energy value (HHV between 15.96 and 20.94

$33 \mathrm{MJ} / \mathrm{kg}$ ) with a great bioactive potential. The released permanent gases show an interesting energy

34 content (LHV up to $11 \mathrm{MJ} / \mathrm{Kg}$ ) which emphasizes their application in a gas engine to provide

35 renewable electricity in rural olive groves area. The recovered OPW biochar presents a high carbon

36 (C 72.54 wt.\%) and nutrients contents (up to $8.42 \mathrm{mg} / \mathrm{g}$ of Ca, up to $8.69 \mathrm{mg} / \mathrm{g}$ of $\mathrm{K}$ and up to

$372.02 \%$ of total $\mathrm{N}$ ) which make it suitable for soil amendment and for long-term carbon

38 sequestration. Kinetic study of OPW pyrolysis, performed using the Distributed Activation Energy

39 Model (DAEM), gives an activation energy values ranging from 121.6 to $151.6 \mathrm{~kJ} / \mathrm{mol}$. The

40 investigation of the OPW thermal behavior and reactivity under pyrolysis conditions is useful

41 approach to design and operate slow pyrolysis process at commercial scale, which could be useful

42 by farmers for OPW in olive fields.

43 Keywords: Pyrolysis, olive pomace wastes, DAEM model, kinetics, biofuels, biofertilizers 


\section{1. Introduction}

46 As a signing party to the 2015 Paris Climate Agreement (COP21), Tunisia has committed to reduce

47 its greenhouse gas emissions, especially in energy sector, with the integration of renewable sources

48 of energy, with a target of at least $30 \%$ of Tunisia's total electricity produced by renewable energy

49 sources in 2030. Among promotive and available renewable resources, biomass and bioenergy

50 from agricultural residues present great potential in Tunisia with an estimated contribution around

51 1.6 Mtep per year, around $10 \%$ of the national needs for primary energy especially for traditional

52 applications in rural regions (cooking, heating, baking needs...)(Haddad 2016).

53 Among Tunisian agricultural by-products, Olive Pomace Waste (OPW) - which are the one of the

54 largest available biomasses in Tunisia - are produced in large quantities (around 400000 tons per

55 year (Mekki et al. 2008)) since Tunisia is the second largest producer of olive oil after the EU,

56 contributing to around $6 \%$ of total production and $18 \%$ of global exports by volume (IOC 2017).

57 The management of olive oil industry residues such as OPW is a typical problem in Tunisia and in

58 other Mediterranean countries and the use of these agricultural residues to produce biofuels and

59 biochemicals facilitates the OPW management in these countries and improves the transition to an

60 efficient circular bio economy based on waste.

61 These OPW are heterogeneous mixture of olive skin, pulp (70-90\%), stone (9-27\%) and olive seeds

62 (2-3\%). The OPW are usually valorised as organic fertilizer via composting (Ameziane et al. 2020;

63 Tsivas et al. 2021) or through direct spreading in agricultural land (Innangi et al. 2017), as source

64 of nutrients and active molecules (Mallamaci et al. 2021; Ribeiro et al. 2021), or also as chemicals

65 feedstock (Paz et al. 2020). The OPW were also reused for crude oil production (Pasqualone et al.

66 2016). The energy recovery of OPW can be performed by alcoholic fermentation for bioethanol

67 production (López-Linares et al. 2020) or by anaerobic digestion for biogas production (Timpanaro 
et al. 2021), or by thermochemical processes which involve combustion, gasification and pyrolysis

69 (De la Torre Maroto et al., 2020; Dorado et al., 2021; Nunes et al., 2020). Knowing the OPW low

70 biodegradability and the high content of organic matter, the thermochemical conversion of these

71 residues has several advantages over conventional biochemical processes as it helps to reduce the

72 process costs by producing economic-value products applicable in several fields: energetic as

73 biofuels, agronomic as biofertilizers and chemical as source of bioactive molecules. Pyrolysis,

74 which is the primary step of all thermochemical processes, is a successfully commercialized

75 technology, which can be suitable for the complete conversion of OPW into liquid (pyrolytic-oil),

76 gaseous (gas) biofuels and solid biochar.

77 Thermogravimetric analysis TGA is applied as a numerical instrument widely used to evaluate

78 kinetic and thermodynamic parameters as well as the impact of different main variables such as

79 temperature, heating rates, and raw material. Many mathematical models have been established to

80 explain the pyrolytic decomposition of biomass using isothermal and non-isothermal TGA

81 measurements. The Distributed Activation Energy Model (DAEM), proposed by (Vand 1943) and

82 summarized by (Miura 1995), suggests that the several heterogeneous chemical reactions that occur

83 during pyrolysis exist simultaneously as irreversible first-order parallel reactions of various rates.

84 This study examines the thermal degradation action, kinetics, and thermodynamics of OPW using

85 the DAEM with the help of thermogravimetric analysis TGA at different heating rates $(5,10$ and

$\left.8620^{\circ} \mathrm{C} / \mathrm{min}\right)$.

87 During last decades, several studies have been accomplished concerning OPW pyrolysis. Table 1S

88 (given as supplementary material) summarizes the most important studies performed on OPW

89 pyrolysis. As it can be observed from literature given in Table 1S, all previous studies focused on

90 the production of biochar and the detailed characterization and application of these chars. Pellera

91 et al (Pellera and Gidarakos 2015) studied the effects of biochar produced by dried olive pomace 
92 pyrolysis at $400^{\circ} \mathrm{C}$ and $700^{\circ} \mathrm{C}$ on the as soil amendments for cadmium and nickel immobilization

93 and reported that the addition of biochar to soil caused an increase in soil $\mathrm{pH}$ and organic matter

94 content. In another study, (Illay 2020) investigated the conversion of OPW in terms of biochar yield,

95 properties, leaching experiment and soil use. Other studies (Aydemir 2014; Khalideh Al bkoor

96 Alrawashdeh et al. 2017; Surahmanto et al. 2020) were interested to the evaluation of the potential

97 for energy production through thermogravimetric analyses and/or through mathematical

98 modelling.

99 To the best of the authors' knowledge, so far, there is no complete experimental and numerical

100 study on OPW pyrolysis for the simultaneous production of biofuels (bio-oil and gas) and

101 biomaterials (biochar). Besides, in Tunisia, OPW recovery via pyrolysis for bioenergy applications

102 is still unknown or not investigated. Thus, this work could be considered as an innovative way to

103 convert OPW into biofuels, biochemicals and biofertilizers. It aims to evaluate, experimentally and

104 numerically, the potentiality of energy valorization of Tunisian OPW through slow pyrolysis

105 process, to recover biofuels (pyrolytic oil and combustible gas) and to recover biomaterials and

106 biochemicals in forms of bioactive molecules from pyrolytic oil and renewable nutrients from

107 biochar.

108 2. Material and methods

109 2.1.Batch pyrolysis plant and Rock-Eval pyrolysis

110 The pyrolysis facility used in this study is a batch laboratory scale pyrolysis plant developed in the

111 Research and the Technology Centre of Energy (CRTEn - Tunisia). The layout of the pyrolysis

112 plant, the detailed procedure of the pyrolysis test and the obtained products yields calculation were

113 advanced by (Trabelsi et al. 2017). Operating parameters were chosen based on TGA/DSC tests as

114 follows: final pyrolysis temperature of 500,600 and $700^{\circ} \mathrm{C}$; heating rate (HR) of $15^{\circ} \mathrm{C} / \mathrm{min}, 20$ 
$115{ }^{\circ} \mathrm{C} / \mathrm{min}$ and $25{ }^{\circ} \mathrm{C} / \mathrm{min}$. During pyrolysis experiment, the reactor is continuously flushed with 116 nitrogen (0.3 1/min). Pyrolytic oil and biochar yields are determined as indicated in Eq. 1.

118 The syngas yield was determined by difference as indicated in Eq. 2:

$$
\text { Syngas }(w t . \%)=100-(\text { pyrolytic oil }(w t . \%)+(\text { biochar }(w t . \%))
$$

120 The Rock-Eval® pyrolysis - which is a basic method for the evaluation of petroleum source rock

121 potentiality in organic geochemistry field - was applied in this study in order to evaluate the

122 potential of OPW to produce thermovaporizable hydrocarbons through pyrolysis process, to

123 estimate the maximum temperature of thermal cracking in inert medium. For this purpose, $17.9 \mathrm{mg}$

124 of the powdered OPW sample was introduced into a steel nacelle. The IFP 160000 sample was

125 used as an external standard. The analytical conditions for the used Bulk Rock method are as

126 follow: the first step which is a pyrolysis step under inert conditions $\left(\mathrm{N}_{2}\right)$ started at $\mathrm{T} 1=300{ }^{\circ} \mathrm{C}$.

127 T1 was maintained as a plateau for 3 minutes. Then, from initial T1, the temperature was 128 programmed to increase at a $\mathrm{HR} 25^{\circ} \mathrm{C} / \mathrm{min}$, up to $\mathrm{T} 2=650{ }^{\circ} \mathrm{C}$. T2 was maintained as a plateau for 1293 minutes. During this step, the thermovaporizable hydrocarbons are released, detected and 130 measured by a flame ionization detector (FID). Thereafter, the nacelle containing the pyrolysis 131 residue is transferred by means of an autosampler into the combustion furnace (air as oxidant 132 agent), under a gradual increase in temperature from $300{ }^{\circ} \mathrm{C}$ to $850{ }^{\circ} \mathrm{C}$ with a $\mathrm{HR} 20^{\circ} \mathrm{C} / \mathrm{min}$. CO 133 and $\mathrm{CO}_{2}$ gases released during pyrolysis and combustion are continuously detected by infrared 134 cells.

\section{$135 \quad$ 2.2.Feedstock and products characterization}

136 OPW samples were provided by a modern unit of olive oil extraction, "Ben Yedder" triphasic 137 centrifugal olive mill, located in Mannouba (near Tunis, Tunisia). The collected samples were first 
138 air-dried and then characterized with their biochars, using proximate analyses according to standard 139 methods (AFNOR, 2010) : (i) AFNORXP CEN/TS 14774-3 for moisture content, (ii) AFNOR XP 140 CEN/TS 14775; ASTM method D-1762-84, ASTM, 1990 for ash content and (iii) ASTM method 141 D-1762-84, 1990 for volatile matter (VM) content. The fixed carbon (FC) content was obtained as 142 indicated in Eq. 3:

$$
F C=D M-(V M+A s h)
$$

144 FC: Fixed Carbon content (\%); DM: Dry Matter content (\%); VM: Volatile Matter content (\%), 145 Ash: ash content (\%).

146 The ultimate composition of OPW and their biochars was determined according to ASTM D537314713 (ASTM, 2008), by means of a Perkin Elmer 2400 model CHN analyzer. The oxygen (O) content 148 was calculated by difference as indicated in Eq. 4:

$$
\boldsymbol{O}(\boldsymbol{w t} . \%)=100-(C+H+N+A s h)
$$

150 The OPW high heating value (HHV) and Low Heating Value (LHV) were calculated according to 151 (Sheng and Azevedo 2005) and (Oyebanji et al. 2018), respectively as indicated in Eq. 5 and 6:

$152 \operatorname{HHV}(\mathrm{MJ} / \mathrm{kg})=-0.3675+0.3137 \mathrm{C}+0.7009 \mathrm{H}+0.0318 \mathrm{O}$

153 LHV $(\mathrm{MJ} / \mathrm{kg})=\mathrm{HHV}-(2.442 \times 8.936(\mathrm{H} / 100))$

154 The inductively Coupled Plasma Optical Emission Spectrometry (ICP-OES) is performed using 155 Agilent $^{\circledR} 5100$ ICP-OES Spectrometer in order to evaluate the potential of OPW and its biochar as 156 soil amendment. The analyzed elements were Al, Ca, Fe, Mg, K, P, Na, Si. For each sample $0.2 \mathrm{~g}$ 157 was calcined at $450{ }^{\circ} \mathrm{C}$ for $3 \mathrm{~h}$, then the cooled ash was stirred for $16 \mathrm{~h}$ with $20 \mathrm{ml}$ of $3.5 \mathrm{M} \mathrm{HCl}$. 158 The mixture was then centrifuged at 4000 tours/min for $15 \mathrm{~min}$ and filtered using $0.45 \mu \mathrm{m}$ filters 159 as described by (Ghanim et al. 2018) and their concentration was calculated as the average of three 160 determination. 
161 The raw material, biochar, and pyrolytic oil were FTIR spectroscopically analyzed using a Perkin

162 Elmer Spectrum BX spectrophotometer in absorbance mode between 4000 and $400 \mathrm{~cm}^{-1}$, on pellets

163 made of a mixture of pre-dried OPW and $0.2 \mathrm{~g} \mathrm{KBr}$ with a ratio of (1: $5 \mathrm{OPW}: \mathrm{KBr}$ ).The FTIR

164 characterization was performed to identify the main functional groups (phenols, alcohols,

165 aliphatics, aromatics, among others) contained in the studied biomass and after thermal treatment

166 to investigate the main components variation.

167 Pyrolytic-oil molecular composition was carried in two steps: (1) a silylation step using BSTFA 168 (N,O-Bis(trimethylsilyl) trifluoroacetamide and $100 \mu \mathrm{l}$ of TMCS (Trimethylchlorosilane) as

169 derivatization reagent in these conditions: $10 \mathrm{mg}$ of pyrolytic-oil was mixed with $100 \mu \mathrm{l}$ of

170 BSTFA. The solution was then mixed on vortex and putted in a bain-marie at $70{ }^{\circ} \mathrm{C}$ during 1 hour.

171 (2) GC/MS molecular analysis of using an Agilent 7890A GC equipped with Agilent 5975C 172 massive-selective detector (MSD). The capillary column is a HP-5MS (5\% diphenyl 95\%

173 dimethylpolysiloxane) capillary column $(30 \mathrm{~m} \times 0.25 \mu \mathrm{m}$ film thickness $)$. The oven temperature

174 program is as follows: initial temperature of $70^{\circ} \mathrm{C}$ during $2 \mathrm{~min}$, then a temperature increase from

175 initial temperature to $300{ }^{\circ} \mathrm{C}$ with a $\mathrm{HR} 7{ }^{\circ} \mathrm{C} / \mathrm{min}$ and finally an isotherm of $10 \mathrm{~min}$ at $300^{\circ} \mathrm{C}$. The

176 injector temperature is about $250{ }^{\circ} \mathrm{C}$. Helium is the vector gas with a flow rate around $1 \mathrm{ml} / \mathrm{min}$.

177 The identification of compounds is determined according to the NIST database.

178 The following AFNOR criteria were used to characterize the bio-oil fuel properties: acidity index

179 (ISO 6618, acid-base titration method); ash content (NF T 60-111, calcination method); HHV (NF

180 M07-030 using an oxygen bomb calorimeter); color (ISO 2049) and flash point (ISO 2719. 2002).

181 The non-condensable gases were first cleaned using a water bubbler to remove the tars, then an 182 activated carbon column to adsorb the remaining dust and particles and finally a set of gas filters

183 before the analysis. A syngas analyzer (GEIT 3160 model) equipped with an IR detector for CO, $184 \mathrm{CO}_{2}, \mathrm{CH}_{4}, \mathrm{C}_{\mathrm{n}} \mathrm{H}_{\mathrm{m}}$ tests, a thermal conductivity detector (TCD) to calculate $\mathrm{H}_{2}$, and an 
185 electrochemical cell for $\mathrm{O}_{2}$ measurements are used to measure and monitor online the chemical

186 composition of syngas.

$187 \quad$ 2.3. Thermal analysis

188 Thermodynamic analysis was done using the thermogravimetric analysis TGA/DSC (TA 189 instruments Q600) to investigate the mass loss mechanism of OPW. After placing the sample in 190 the TGA, the temperature was increased from room temperature to $1000^{\circ} \mathrm{C}$ at the several $\mathrm{HRs} 5$,

19110 and $20^{\circ} \mathrm{C} / \mathrm{min}$. Throughout the procedure, continuous flow nitrogen at $100 \mathrm{ml} / \mathrm{min}$ was used.

192 2.4.Kinetic analysis via distributed activation energy analysis model

193 The DAEM is widely used as a convenient method to identify the thermal kinetic parameters and

194 the complex reactions that occur during pyrolysis of biomass (Yaras et al. 2021). For

195 lignocellulosic materials, the DAEM investigated the totality of volatiles released or the amount of 196 an individual volatile constituent. The DAEM presents a great harmony with the experimental data

197 to understand the pyrolysis kinetics of biomass especially at low HRs (Qi et al. 2021) . DAEM 198 involves parallel, dependent and first-to-n-order reactions with activation energies, and various 199 activation energies reveal the binding properties of biomass components. The DAEM method 200 assumes that all reaction activation energies have the same pre-exponential factor $\mathrm{k}_{0}$ at the same 201 conversion rate, and the activation energies have a continuous distribution.

202 The devolatilization process can be explicit in this way Eq. 7:

$$
1-V / V^{*}=\int_{0}^{\infty} \exp \left(-\frac{k_{0}}{\beta} \int_{0}^{t} e^{-E / R T} d T\right) f(E) d E
$$

204 The DAEM represents the change of the total volatile matter of the solid where V is the volatile 205 matter content at the absolute temperature $\mathrm{T}$ when the $\mathrm{HR}$ is $\beta, \mathrm{V} / \mathrm{V} *$ is the effective volatile matter 206 content of the solid ( $\mathrm{V}^{*}$ is the effective volatile content at any time $\mathrm{t}$ ), and $\mathrm{k}_{0}$ is the frequency factor 
207 corresponding to the given $\mathrm{E}$ value. $\mathrm{f}(\mathrm{E})$ is the activation energy distribution curve, which

208 encapsulates the range and change of the activation energy of the first-order irreversible reaction

209 at the same time.

210 Miura and Maki.(Miura 1995) have simplified distribution function as indicated in Eq. 8:

211

$$
v / v^{*}=1-\int_{E_{a}}^{\infty} f\left(E_{a}\right) d E_{a}=\int_{0}^{E_{a}} f\left(E_{a}\right) d E_{a}
$$

212 The DAEM Eq. obey to Arrhenius Eq. law and is simplify in this way Eq. 9:

$213 \ln \left(\frac{\beta}{T^{2}}\right)=\ln \left(\frac{R k_{0}}{E_{a}}\right)+0.6075-\frac{E_{a}}{R} \frac{1}{T}$

214 The activation energy $E_{a}$ and related frequency factor in eq.(9) are calculated using three unique

215 TGA curves, each with its unique HR, by graphing the natural $\log$ of $\left(\mathrm{a} / \mathrm{T}^{2}\right)$ vs inverse temperature 216 at different conversion $\left(\mathrm{V} / \mathrm{V}^{*}\right)$ values. As a result, the activation energy obtained from the

217 Arrhenius plots base on Eq. 9 represents amount of solid pyrolysis degradation.

218 3. Results and discussion

\section{3.1.OPW characteristics}

220 The OPW proximate parameters are summarized in Table 1. OPW presents a high VM content 221 about $73 \mathrm{wt} . \%$ on dry basis which shows the promoting potential of devolatilization of the biomass 222 (Alcazar-Ruiz et al. 2021) and relatively low ash content (about 2\%) compared to other olive 223 residues reported in literature (Dorado et al. 2021) (Table 1). The OPW moisture content as 224 received is about $10.44 \mathrm{wt} . \%$ and it reaches $3.44 \%$ after air-drying, which is tolerable for 225 thermochemical conversion via pyrolysis process since moisture content is one of the main 226 parameters in biomass pyrolysis, because it inhibits the process if it surpasses $10 \%$ by weight 227 (Alcazar-Ruiz et al. 2021). 
The CHN-O elemental composition of studied OPW reveals high carbon and hydrogen contents (C 47.3 wt. $\%$ and $\mathrm{H} 6.6$ wt.\%, respectively) which are comparable to those reported in previous studies 230 ((Khalideh Al bkoor Alrawashdeh et al. 2017; Dorado et al. 2021), Table 1). The OPW nitrogen 231 content is relatively high compared to other lignocellulosic biomass indicating the potential use of 232 the residual pyrolytic char as nutrient-rich fertilizer. Based on the $\mathrm{CHN}-\mathrm{O}$ elemental composition, 233 the calculated $\mathrm{HHV}$ of OPW is around $20.48 \mathrm{MJ} / \mathrm{kg}$ (Table 1), which is comparable to those 234 reported for other olive pomace substrates (20.30 MJ/kg, (Aydemir 2014); and 19.88 MJ/kg; 235 (Khalideh Al bkoor Alrawashdeh et al. 2017). To be used as solid fuel directly, a thermal treatment 236 step (such as a slow pyrolysis) is required to enhance the POW calorific value.

237 OPW mineral composition, given in Table 1, reveals the richness of OPW with $\mathrm{K}(6.46 \mathrm{mg} / \mathrm{g}$ of 238 sample) and $\mathrm{Ca}(4.64 \mathrm{mg} / \mathrm{g}$ of sample). The concentrations of other elements are ranging from 0.21 $239 \mathrm{mg} / \mathrm{g}$ of sample for $\mathrm{Na}$ to $0.43 \mathrm{mg} / \mathrm{g}$ of sample for $\mathrm{P}$. The high amounts of $\mathrm{K}$ and $\mathrm{Ca}$ emphasize the 240 use of the obtained biochars as nutrient rich amendment. Besides, the occurrence of inorganic 241 minerals in raw biomass could be an important factor to consider because some minerals especially 242 the alkali (K, Na, etc.) and alkaline- earth metals ( $\mathrm{Mg}, \mathrm{Ca}$, etc.) could have acted as catalysts during 243 thermal process (Dinc and Yel 2018; Alcazar-Ruiz et al. 2021). While studying the effect of 244 inorganic metals ( $\mathrm{K}, \mathrm{Mg}$ and $\mathrm{Ca}$ ) on thermal degradation of lignocellulosic biomass, reported that 245 the $\mathrm{K}$ contained in the lignocellulosic biomass has a catalytic effect by favoring solid char 246 formation and by decreasing bio-oil yield, whereas $\mathrm{Mg}$ and Ca have some effects on the biomass 247 degradation rate. In the case of OPW, the high content of K leads these substrates suitable for char 248 production whereas the presence of $\mathrm{Ca}$ seems to not giving changes in the formation of pyrolytic 249 compounds (Eom et al. 2012).

250 The pre-dried OPW FTIR spectrum given in Figure SI 1 shows a large band centred on $3369 \mathrm{~cm}^{-1}$ 251 attributed to the stretching vibration of $\mathrm{O}-\mathrm{H}$ contained in phenols and alcohols. Then, two intense 
252 peaks at $2921 \mathrm{~cm}^{-1}$ and $2852 \mathrm{~cm}^{-1}$ could be related to the stretching vibration of $\mathrm{C}-\mathrm{H}$ in the lignin 253 structure (Fan et al. 2017) and also to methylene and methyl groups of fatty acids since OPW 254 contains remaining olive oil. The weak peaks centered on 1436 and $1379 \mathrm{~cm}^{-1}$ correspond to the 255 asymmetric bending of C-C in the lignin structure (Lestander et al. 2018). Besides, another peak 256 around $1245 \mathrm{~cm}^{-1}$ could be attributed to the presence of $\mathrm{C}-\mathrm{O}-\mathrm{C}$ in the cellulose biopolymer chain

257 (Dorado et al. 2021). Moreover, the intense band centered on $1058 \mathrm{~cm}^{-1}$ showed a high intensity 258 peak which could be associated to $\mathrm{C}-\mathrm{O}-\mathrm{H}$ stretching vibrations linkages in cellulose and 259 hemicellulose or to the presence of C-O-R in alcohols or esters (Ceylan and Goldfarb 2015). The 260 large band centred around $600 \mathrm{~cm}^{-1}$ is usually associated with aromatic compounds (Fan et al. 261 2017). OPW are complex and heterogeneous materials with a remaining fatty acids and with a 262 considerable lignocellulosic phase (around $21.5 \%$ of cellulose, $24.3 \%$ of hemicelluloses and 38.0 $263 \%$ of lignins (García-Ibañez et al. 2006)). FTIR spectroscopy has proved to be powerful tool to 264 comply with the purpose of comprehensive characterization of these local agricultural by-products.

265 The OPW mass loss (TG) and the derivative mass loss (DTG) curves with respect to temperature 266 in the $\mathrm{N}_{2}$ atmosphere at $10^{\circ} \mathrm{C} / \mathrm{min}$ are given in Figure 1 . As it can be seen from the obtained results, 267 the DTG curve revealed three classic degradation steps. The first mass loss step occurred at low 268 temperatures $\left(<180{ }^{\circ} \mathrm{C}\right)$ and it attributed to moisture release. The second mass loss step, which is 269 the key pyrolysis stage of OPW, happened between 180 and $600{ }^{\circ} \mathrm{C}$ and is usually associated to 270 the primary devolatilization of the main components. A great part of volatiles are released between $271 \quad 180$ and $400{ }^{\circ} \mathrm{C}$ whereas lignins continue their degradation after $400{ }^{\circ} \mathrm{C}$. (Bensidhom et al. 2018) 272 reported that the most critical devolatilization of biomass enclosed by 180 and $400{ }^{\circ} \mathrm{C}$, it is known 273 as the active pyrolysis zone. Within the devolatilization zone, it can be seen that two zones could 274 be observed: the first between 180 and $340{ }^{\circ} \mathrm{C}$ that involves the hemicelluloses and cellulose 275 degradation. The lignins decomposition starts after $350{ }^{\circ} \mathrm{C}$ with a slow rate (Bensidhom et al. 
2021), more it gradually debases up to the ultimate pyrolysis temperature of $600{ }^{\circ} \mathrm{C}$. After this

277 temperature, the passive zone started where the devolatilization practically finished and there is no

278 loss of additional mass. Similar results were reported by (Dorado et al. 2021) when the temperature

279 reaches $600^{\circ} \mathrm{C}$, the weight loss rate was about $0 \%$ wt./min.

\section{$280 \quad$ 3.2.Rock-Eval ${ }^{\circledR}$ pyrolysis results}

281 The POW Rock-Eval ${ }^{\circledR}$ analysis - applied in order to investigate the OPW thermal behaviour and to

282 evaluate their potential to produce hydrocarbons - reveals some valuable indicators show on Figure

283 SI 2, which are mostly: the Total Organic Carbon (TOC) is around $43.5 \%$ whereas the mineral 284 carbon (Cmin) is around $1.8 \%$. The $\mathrm{S} 1$ parameter, which is around $103.2 \mathrm{mg} / \mathrm{g}$ indicating that POW 285 contains high amounts of hydrocarbons already present whereas the S2 parameter is around 125.1

$286 \mathrm{mg} / \mathrm{g}$ which indicates that the hydrocarbons produced during pyrolysis reveals that POW are 287 promising raw materials to produce volatiles during thermal cracking. The relative amounts 288 of S1 and S2 are dependent on the type of organic matter and on the thermal energy (time and 289 temperature). The Tmax parameter is around $315^{\circ} \mathrm{C}$. Tmax corresponds to the temperature at the 290 maximum production of hydrocarbons during pyrolysis gives an indication of the temperature of 291 the maximum of the production of volatiles. The Hydogen Index (HI) is around $288 \mathrm{mg}$ of HC/g 292 of TOC of the sample. The high IH indicate the good potential of OPW to produce di-hydrogen.

293 The oxygen index (OI) is around 165 of $\mathrm{CO}_{2} / \mathrm{g}$ of TOC of the sample. The oxygen index is 294 associated to the lignin-cellulose and hemicellulose contents.

\section{3.3.Pyrolytic products distribution}

\section{3.3.1. Effect of final pyrolysis temperature}

297 The investigation of the effect of the final pyrolysis temperature $\left(500,600\right.$ and $\left.700{ }^{\circ} \mathrm{C}\right)$ at constant 298 HR $\left(15^{\circ} \mathrm{C} / \mathrm{min}\right)$ on the pyrolysis products distribution (Figure 2) indicates that the liquid oil yield 
299 increases from $26 \mathrm{wt} . \%$ at $500{ }^{\circ} \mathrm{C}$ to $33 \mathrm{wt} . \%$ at $600{ }^{\circ} \mathrm{C}$ and then decreases up to $27 \mathrm{wt} . \%$ at 700

$300{ }^{\circ} \mathrm{C}$. The enhancement of the bio-oil yield with the temperature increase is due to the emphasis of

301 the primary pyrolysis reactions (devolatilization) with thermal stress (Brindhadevi et al. 2021).

302 However, the decrease of the oil fraction at much higher temperature could be attributed to the 303 occurrence of secondary pyrolysis reactions and namely to vapors cracking and gasification at high

304 temperature (Irfan et al. 2016). Thus, $600{ }^{\circ} \mathrm{C}$ was retained as the optimal condition for the

305 maximum production of oil fraction. The secondary reactions of volatiles cracking into small

306 gaseous molecules, occurring at high temperature are confirmed by the increase of syngas yield at

$307700{ }^{\circ} \mathrm{C}(47 \mathrm{wt} . \%)$ compared to $600{ }^{\circ} \mathrm{C}(37 \mathrm{wt} . \%)$. For the solid char, we distinguish a monotonous

308 amount decrease from $32 \mathrm{wt} . \%$ at $500{ }^{\circ} \mathrm{C}$ to $30 \mathrm{wt} . \%$ at $600{ }^{\circ} \mathrm{C}$ and to $26 \mathrm{wt} . \%$ at $700{ }^{\circ} \mathrm{C}$. This

309 tendency may be explained by the further degradation of organic materials with temperature

310 increase (Li et al. 2021).

\section{$311 \quad$ 3.3.2. Effect of the heating rate}

312 The results of the investigation of the effect of the pyrolysis $\mathrm{HR}\left(15^{\circ} \mathrm{C} / \mathrm{min}, 20^{\circ} \mathrm{C} / \mathrm{min}, 25^{\circ} \mathrm{C} / \mathrm{min}\right)$

313 at constant temperature $\left(600^{\circ} \mathrm{C}\right)$ on the recovered products distribution are given in Figure 2.

314 According to these results, a decrease in the bio-oil yield (from $33 \%$ at $15^{\circ} \mathrm{C} / \mathrm{min}$ to $29 \%$ at 20 and $31525^{\circ} \mathrm{C} / \mathrm{min}$ ) and an improvement in the gas yield, with the $\mathrm{HR}$ increase from $15^{\circ} \mathrm{C} / \mathrm{min}$ to $25^{\circ} \mathrm{C} / \mathrm{min}$

316 are observed. Xiong et al. (Xiong et al. 2018) reported that a large proportion of bio-oil might be

317 evaporated as gas phase volatile at fast $\mathrm{HR}$ and for temperature more than $500^{\circ} \mathrm{C}$. For the solid

318 fraction, the mass yield is almost constant (around 30\%) for all HR; this indicates that the higher

319 HR promoted the cracking of the organic components remaining in the char and the condensable

320 volatiles to form the gaseous products [37].

\section{$321 \quad$ 3.4.Pyrolysis products characteristics}




\subsubsection{Pyrolytic oil properties}

323 The CHN-O elemental composition of recovered oils at different temperature and HR are given in

324 Table 2. The CHN-O results show that the $\mathrm{C}$ content ranges from 50.58 to $67.55 \mathrm{wt} \%$, the $\mathrm{H}$

325 content ranges from 6.99 to $9.85 \mathrm{wt} . \%$ and the $\mathrm{O}$ is between 22.25 and $39.05 \mathrm{wt} . \%$. These findings

326 are comparable to those published for bio-oils derived from olive oil residues from several origins

327 reported by Guida et al. (Guida 2017). The pyrolytic oil HHV increased from 22.9 to $23.49 \mathrm{MJ} / \mathrm{kg}$

328 while temperature increases from $500^{\circ} \mathrm{C}$ to $700^{\circ} \mathrm{C}$, and then slightly decreased until $27.81 \mathrm{MJ} / \mathrm{kg}$

329 with the increase of $\mathrm{HR}$ at $25^{\circ} \mathrm{C} / \mathrm{min}$.

330 The fuel properties of the recovered organic fraction at final temperature $600^{\circ} \mathrm{C}$ and $\mathrm{HR} 15^{\circ} \mathrm{C} / \mathrm{min}$

331 are reported in Table 2 . The acidity index is relatively high ( $72 \mathrm{mg}$ de $\mathrm{KOH} / \mathrm{g}$ sample) and have to

332 be improved to reach the values required by petroleum derivates standards (acidity index do not

333 exceed $5 \mathrm{mg} \mathrm{KOH} / \mathrm{g}$ of sample for Tunisian Diesel(Amdouni et al. 2021). The measured HHV is

334 about $17.79 \mathrm{MJ} / \mathrm{kg}$ and the flash point was $44^{\circ} \mathrm{C}$, the ash content $0.012 \%$ and the color was DIL8.

335 These fuel properties are in the same range that those reported for other pyrolytic oils by

336 (Channiwala and Parikh 2002).

337 The OPW pyrolytic oil FTIR spectra in all experimental conditions are given in Figure SI 1. From

338 the obtained patterns, it is noted that all recovered bio-oils are composed of high amount of

339 hydroxyl (-OH) groups contained in alcohols, phenols and in water obtained in the band $3400 \mathrm{~cm}^{-}$

$340{ }^{1}$. The absorbance of the band between 2800 and $3000 \mathrm{~cm}^{-1}$ (assigned to C-H) disappear in bio-oil

341 spectra compared to the raw material which indicates the degradation of aliphatic compounds under

342 heating (Fan et al. 2017). The aromatic groups are present in all pyrolytic-oils at $1690 \mathrm{~cm}^{-1}(\mathrm{C}=\mathrm{C})$

343 and $1450 \mathrm{~cm}^{-1}(\mathrm{C}-\mathrm{O})$. For the bands between $1475 \mathrm{~cm}^{-1}$ and $1000 \mathrm{~cm}^{-1}$ when the temperature

344 increased to $700{ }^{\circ} \mathrm{C}$ and $\mathrm{HR}$ raised to $25^{\circ} \mathrm{C} / \mathrm{min}$, the peaks are well distinguished which indicates

345 that the alcohols, phenols and ethers groups are still present in the pyrolytic oils (Ceylan and 
346 Goldfarb 2015). The OPW bio-oil FTIR characterization revealed that it is a complex mixture

347 consisting of different classes of functional groups, i.e., aliphatic, aromatic and oxygenated 348 compounds.

349 The GC/MS investigation leads to the identification of potential bioactive chemical constituents 350 contained in pyrolytic bio-oils produced from OPW at different pyrolysis conditions. The obtained

351 results (Table SI 2 and Figure SI 3) indicates that around thirty-seven compounds have been

352 identified. These compounds are mainly fatty acid esters, phenols and nitrogenous

353 compounds...etc. The major components identified in OPW pyrolysis bio-oils identified as

354 trimethylsilyl (TMS) derivatives were: (i) organic acids with 82.6\%; (ii) Nitrogenous compounds

355 with 7.4\%; (iii) Phenolic compounds with $4.2 \%$ for BO-OMW; (iv) Monoglycerides with $1.8 \%$.

356 The antibacterial, antifungal, antioxidant, anti-cancer, anti-inflammatory, and

357 hypocholesterolaemia activities of the majority of the discovered compounds have been noted in 358 the literature.

359 Importantly, GC/MS results showed that OPW pyrolytic oils are potential antioxidant agents with 360 many bioactive phytochemical compounds. This is not surprising to find such active molecules in

361 studied pyrolytic bio-oils because in traditional medicine in Tunisia, the pyrolysis tars coming from

362 mainly olive tree by-products carbonization are used as a popular remedy and as an additive to

363 drinking water as flavouring agent in drinking water.

\section{3.4.2. Char charateristics}

365 The ultimate and proximate analysis and HHVs for the chars produced by quick pyrolysis of olive

366 pomace at various temperatures and HR are shown in Table 2. Carbon is the most prevalent

367 ingredient in chars, far exceeding amounts present in raw materials. The $\mathrm{C}$ content increased as the

368 pyrolysis temperature increased, while the $\mathrm{H}$ and $\mathrm{O}$ contents decreased. Higher temperatures 369 promote the scission of weaker bonds within the char structure, which results in hydrogen and 
370 oxygen losses. The chars' HHVs were about 24 and $25 \mathrm{MJ} / \mathrm{kg}$, which are comparable to solid fossil

371 fuels like lignite and anthracite (Raveendran and Ganesh 1996), implying that the chars could be

372 used as solid fuels.

373 The ultimate, $\mathrm{CHN}$, and elemental analyses of the created char are shown in Table 2. The existence

374 of a residual percentage of volatiles in the char, ranging between 34.8 and $43.9 \%$, indicates that the

375 pyrolysis processes did not complete at the target temperature of $600{ }^{\circ} \mathrm{C}$.

376 The recovered chars FTIR spectra obtained at various temperatures and HRs (Figure SI 1) show

377 the absence of the $\mathrm{OH}$ bands at $3400 \mathrm{~cm}^{-1}$ attributed to alcohols and phenols while the presence of

378 aliphatic groups (alkanes). This absorbance of the band between 2700 and $3000 \mathrm{~cm}^{-1}$ (ascribed to

$379 \mathrm{C}-\mathrm{H})$ in biochar is weak and disappear with the temperature increase up to $700^{\circ} \mathrm{C}$ which indicates

380 the presence of alcohol and carboxylic acid (Fan et al. 2017). The aromatic groups are present in

381 all the chars at band around 1690 and $1450 \mathrm{~cm}^{-1}$. For the bands between $1475 \mathrm{~cm}^{-1}$ and $1000 \mathrm{~cm}^{-1}$

382 when the temperature and $\mathrm{HR}$ increase to $700{ }^{\circ} \mathrm{C}$ and $25^{\circ} \mathrm{C} / \mathrm{min}$, respectively, the spectra of the

383 chars became nearly flat, which indicates that the alcohol, phenol and ether groups (C-O) were lost

384 (Ceylan and Goldfarb 2015) compared to the raw material which confirm the results obtained by

385 the $\mathrm{CHN}-\mathrm{O}$ analysis.

386 SEM results were used to determine the morphology of the $\mathrm{OPW}$ char produced at $600^{\circ} \mathrm{C}$ with

$38715^{\circ} \mathrm{C} / \mathrm{min}$ as $\mathrm{HR}$. As Figure 3 shows, the recovered biochar shows a porous structure on the surface

388 with pore sizes until $50 \mu \mathrm{m}$. This integrated structure without considerable pores could be

389 associated with the release of VM under heating and the loss of the original structure of the raw

390 material which is composed by lignin, cellulose and hemicelluloses (Dorado et al. 2021). This leads

391 to the formation of large pores suitable for the adsorption process and the removal of organic and

392 inorganic contaminants in aqueous solutions (Sizirici et al. 2021). In addition, the SEM patterns

393 reveal the presence of some needle like crystals, formed and distributed on the char surface, which 
394 confirmed the elemental results by ICP (P and K richness) and which emphasizes its use as fertilizer

395 (An et al. 2020).

\section{3.4.3. OPW Gas composition}

397 The recovered non condensable gas composition obtained at $600^{\circ} \mathrm{C}$ and $15^{\circ} \mathrm{C} / \mathrm{min}$ indicate that it 398 is a complex mixture of $\mathrm{CO}$ (up to 41.1 wt. \%), $\mathrm{CO}_{2}$ (up to 0.59 wt. \%), $\mathrm{H}_{2}$ (up to 4.63 wt. \%), $\mathrm{CH}_{4}$ 399 (up to 6.87 wt. \%) and $\mathrm{C}_{\mathrm{n}} \mathrm{H}_{\mathrm{m}}$ (up to 1.72 wt. \%). Due to the high yield of methane $\left(\mathrm{CH}_{4}\right.$ ), carbon 400 monoxide $(\mathrm{CO})$, and di-hydrogen $\left(\mathrm{H}_{2}\right)$, the gas has a high energy content (LHV approximately 8.14 $401 \mathrm{MJ} / \mathrm{Nm}^{3}$ ), which allows it to be utilized as an alternative fuel source for internal combustion 402 engines and industrial combustion operations, as well as to supply heat for the pyrolysis process.

\section{3.5.Kinetics of thermal decomposition}

404 Many researches are focusing on numerical modelling in order to have a better understanding of 405 the pyrolysis process. In fact, modelling is a mathematical methodology that allows for the

406 following: assessing the performance of pyrolysis; investigating the possibilities of optimizing their 407 performance in order to achieve desired product yields and distribution; saving time and money, 408 particularly for full-scale processes; and forecasting and studying biomass thermal breakdown and 409 studying the influence of different operating conditions. The different elements of equilibrium and

410 kinetics models of the thermochemical process have been explored numerically (Baruah and 411 Baruah 2014; Sharma et al. 2015; Solarte-Toro et al. 2021). The non-isothermal TG/DTG 412 experimental results of the pyrolysis of the studied sample olive pomace at 5,10 and $20^{\circ} \mathrm{C} / \mathrm{min}$ in 413 an inert environment were used for kinetic modelling Figure 4. The results show that the 414 devolatilization occurs when the temperature elevated with the increase of the HR.

415 Thermal DTG confirmed that the degradation of biomass started from $230^{\circ} \mathrm{C}$ to $360^{\circ} \mathrm{C}$. The plots 416 presented by DAEM are non-linear and show different behaviours. This phenomenon may be 
417 caused by multiple chemical reactions occurring at the same time. As shown in Table 4, through

418 the conversion value (x) from 0.2 to 0.8 , the correlation coefficient $\left(\mathrm{R}^{2}\right)$ varies between 0.94 and

4190.99 , indicating the best model fitting value. The activation energy calculated using the DEAM

420 model is between 121.6 and $151.1 \mathrm{~kJ} \mathrm{~mol}^{-1}$. In addition, the frequency factor $\left(\mathrm{k}_{0}\right)$ varies from

$421 \quad 1.69 \cdot 10^{10}$ to $9.86 \cdot 10^{13}$. The kinetic results confirmed that the activation energy depends on the

422 conversion value, which indicates that the olive pomace experienced complex degradation

423 processes related to various reactions. The relevant Equations and coefficients obtained using the

424 equations are listed in Table 4. Figure 4 shows the iso-conversion diagram, as well as the activation

425 energy and frequency factor obtained at each conversion level. Since the correlation coefficient

$426\left(\mathrm{R}^{2}\right)$ of each conversion point is greater than 0.94 , we believe that the hypothesis of DAEM and its

427 multiple simultaneous primary decomposition reactions is a reasonable model for predicting the

428 activation energy of olive pomace pyrolysis. The activation energy of pyrolysis is between 121.6

429 and $151.6 \mathrm{~kJ} / \mathrm{mol}$, with an average value of $138.1 \pm 11.9 \mathrm{Kj} \mathrm{mol}^{-1}$. As the thermal decomposition

430 progresses, the apparent activation energy value changes with the conversion rate, thus

431 emphasizing the complex mechanism of pyrolysis, which changes with the change of the material

432 composition. However, as shown in Figure 4, we found a good agreement between the TG curves

433 calculated using the kinetic parameters obtained from DAEM and the measured data at each HR.

434 Therefore, we are confident in the applicability of DAEM in describing the complex pyrolysis

435 reaction of UP degradation.

436 The activation energy calculated here has advantages over the pyrolysis activation energy of 437 lignocellulose using the DAEM method and different models in the literature, as shown in Table 438 5. Diverse models have been applied to Olive oil residues such as KAS, FO, FWO and other 439 modified model (Buratti et al. 2016; Guida and Hannioui 2016; Martín-Lara et al. 2017, 2018; 440 Sfakiotakis and Vamvuka 2018). The originality for applying DAEM model to these types of Olive 
441 waste is that it is done for the first time (no published data of DAEM with olive pomace).

442 Moreover, according to the recommendations of the ICATC: International Confederation for

443 Thermal Analysis and Calorimetry (ICTAC), the DAEM is recommended. Using the FWO method

444 the activation energy of olive pomace is calculated and ranging from 116 to $203.0 \mathrm{~kJ} \mathrm{~mol}^{-1}$ at $\mathrm{HRs}$

4452 to $20 \mathrm{~K} \mathrm{~min}^{-1}$ (Khalideh Al bkoor Alrawashdeh et al. 2017) and using the KAS method is ranged

446 from 35.77 to $247.8 \mathrm{~kJ} \mathrm{~mol}^{-1}$ at $\mathrm{HRs} 5$ to $25^{\circ} \mathrm{C} \min ^{-1}$ (Ghouma et al. 2017). Other researchers

447 determined, the activation energy of olives at HRs of 5, 10, and $15 \mathrm{~K} \mathrm{~min}^{-1}$ using two models,

448 DAEM and FWO, respectively, which were 110, 18 and $113.8 \mathrm{~kJ} \mathrm{~mol}^{-1}$ (Fernandez et al. 2018).

449 (Çepelioğullar et al. 2018) have also determined the activation energy for olive oil residue (OOR)

450 and other Lignocellulosic forest residue (LFR) with different model Friedman, FWO, and KAS,

451 respectively and they found that the activation energy have the same value for each biomass about

$452186 \mathrm{~kJ} \mathrm{~mol}^{-1}$ for OOR and about $155 \mathrm{~kJ} \mathrm{~mol}^{-1}$ for LFR at $\mathrm{HRs} 5,10,20$ and $50^{\circ} \mathrm{C} \mathrm{min}^{-1}$. (Biagini

453 et al. 2008) employed different HRs 5, 10, 15, 20, 40, 60 and $100 \mathrm{~K} \mathrm{~min}^{-1}$ for olive cake and they

454 reported that the activation energy found were 112.1, 117.8 and $103.2 \mathrm{~kJ} \mathrm{~mol}^{-1}$ using Friedman

455 FWO, and KAS models, respectively. The activation energy value of biomass obtained by analysis

456 of the fuel produced (bio-oil and produced gas) and the characteristics of biochar is important to

457 know to optimize the process of fuel recovery and recovery of the biochar produced.

458 3.6.Future Application of the OPW pyrolysis products

459 Pyrolysis as a thermochemical conversion technique and one of the promising process in recent 460 years (Das et al. 2021), It presents a multiple advantages such as saving the environment from the 461 negative impact of wastes and creating usable feedstock's without damaging the environment. It 462 converts waste into three different products. The bio-char recovered in this study from OPW 463 pyrolysis can be used in the future as organic fertilizers, amendment, activated carbon and 
464 adsorbent. Beyond the possible use of produced bio-oil as alternative liquid biofuel in the traffic

465 sector, there is an interest in its application as source of fine chemicals and bio-active molecules.

466 Therefore, based on biochemical compounds exploration and function identification, sustainable

467 and innovative application path of pyrolytic-oil as precursor of active molecules have to be 468 developed for the enhancement of the pyrolysis process efficiency. Furthermore, the syngas

469 produced could be used in the combustion in boilers and generators and as a supporting agent in

470 the pyrolysis process by supplying heat in the pyrolyzer.

\section{4. Conclusion}

472 Based on the findings of this study, we can claim that energy recovery of OPW by pyrolysis is a 473 promising methodology for addressing environmental issues associated with by-products of olive 474 oil extraction processes and turning these organic wastes into usable products. The experimental 475 study reveals that in the optimum conditions $\left(600^{\circ} \mathrm{C}\right.$ and $15^{\circ} \mathrm{C}$ min-1), up to $33.3 \mathrm{wt} . \%$ of oil, 30 476 wt.\% of char and 36.7 wt.\% of gas were produced. The recovered pyrolytic oil have a low HHV 477 and show a good bioactive potential (antioxidant, antimicrobial, etc.). The OPW remaining char 478 presents high $\mathrm{C}$ amount and high nutrients contents that makes it suitable for amendment in 479 agricultural soils and for long term carbon sequestration. The released non condensable gases show 480 high energy content (LHV around 8.14 $\mathrm{MJ} / \mathrm{Nm}^{3}$ ) suitable for its application as an alternative fuel 481 source or to supply heat for driving the pyrolysis process. The DAEM may be used to calculate the 482 kinetic parameters of pyrolysis and offers a satisfactory match to the experimental data.

483 This integrated novel approach of bio-valorisation of OPW into renewable fuels and high-value 484 added materials can be adopted by olive farmers and industrials to convert these olive residues into 485 wealth.

486 - Acknowledgements 
This work is carried out in collaboration between University of Liemerick (Faculty of Engineering,

488 Chemical Engineering Department), Ondokuz Mayıs University (Faculty of Engineering, 489 Chemical Engineering Department, Samsun, Turkey) and Research and Technology Centre of 490 Energy, Technopôle Borj-Cedria, Tunisia. This work was supported and funded by the Ministry of 491 Higher Education and Scientific Research (MESRST) in Tunisia and under a Contract between the 492 MESRST and the Research and Technology Centre of Energy (CRTEn). The authors gratefully 493 acknowledge the Tunisian Ministry of Higher Education and Research for financial support.

495 - Ethical Approval

$496 \quad$ o Not applicable

497 - Consent to Participate

$498 \quad \circ \quad$ Not applicable

499 - Consent to Publish

$500 \quad \circ$ Not applicable

501 - Authors Contributions

$502 \quad \circ$ Mohamed Hechmi Aissaoui: carried out experimental work; interpreted results and

503 has a major contribution in the redaction of the manuscript;

$504 \quad \circ$ Aïda BEN HASSEN TRABELSI: verified the analytical results; supervised the 505 findings of this work and has a major contribution in the redaction of the manuscript;

$506 \quad 0$ Gmar Bensidhom: helped in numerical verification and their results interpretation;

$507 \quad \circ$ Selim Ceylan: contributed in results discussion, numerical verification and 508 manuscript revision

$509 \quad \circ$ James J Leahy: contributed in results acquisition, discussion and manuscript revision 
○ Witold Kwapinski: contributed in results acquisition, discussion and manuscript revision

512 All authors discussed the results, provided critical feedback and helped shape the research, analysis

513 and manuscript.

$514 \quad-\quad$ Funding

$515 \quad \circ$ This work was supported and funded by the Ministry of Higher Education and

516 Scientific Research (MESRST) in Tunisia and under a Contract between the

517 MESRST and the Research and Technology Centre of Energy (CRTEn).

$518 \quad$ Availability of data and materials

$519 \quad$ O Not applicable

520 - Competing Interests

$521 \quad 0$ The authors have no conflicts of interest to declare that are relevant to the content of this article. All authors certify that they have no affiliations with or involvement in any organization or entity with any financial interest or non-financial interest in the subject matter or materials discussed in this manuscript. The authors have no financial or proprietary interests in any material discussed in this article.

\section{References}

528 Alcazar-Ruiz A, Garcia-Carpintero R, Dorado F, Sanchez- Silva L (2021) Valorization of olive 529 oil industry subproducts: ash and olive pomace fast pyrolysis. Food Bioprod Process 530 125:37-45. https://doi.org/10.1016/j.fbp.2020.10.011

531 Amdouni S, Ben Hassen Trabelsi A, Mabrouk Elasmi A, et al (2021) Tannery fleshing wastes 532 conversion into high value-added biofuels and biochars using pyrolysis process. Fuel 294:. 
534 Ameziane H, Nounah A, Khamar M, Zouahri A (2020) Composting olive pomace: Evolution of 535 organic matter and compost quality. Agron Res 18:5-17.

$536 \quad$ https://doi.org/10.15159/AR.20.004

537 An X, Wu Z, Yu J, et al (2020) Copyrolysis of Biomass, Bentonite, and Nutrients as a New

538 Strategy for the Synthesis of Improved Biochar-Based Slow-Release Fertilizers. ACS

539 Sustain Chem Eng 8:3181-3190. https://doi.org/10.1021/acssuschemeng.9b06483

540 Aydemir SBK and H (2014) Pyrolysis of Olive Pomace and Copyrolysis of Olive Pomace with

541 Refuse Derived Fuel. Am Inst Chem Eng Env 8:649-656. https://doi.org/10.1002/ep

542 Baruah D, Baruah DC (2014) Modeling of biomass gasification: A review. Renew Sustain

$543 \quad$ Energy Rev 39:806-815. https://doi.org/10.1016/j.rser.2014.07.129

544 Bensidhom G, Ben Hassen-Trabelsi A, Alper K, et al (2018) Pyrolysis of Date palm waste in a

545 fixed-bed reactor: Characterization of pyrolytic products. Bioresour Technol 247:363-369.

$546 \quad$ https://doi.org/10.1016/j.biortech.2017.09.066

547 Bensidhom G, Ben Hassen Trabelsi A, mahmood MA, Ceylan S (2021) Insights into pyrolytic

548 feedstock potential of date palm industry wastes: Kinetic study and product characterization.

$549 \quad$ Fuel 285:119096. https://doi.org/10.1016/j.fuel.2020.119096

550 Biagini E, Fantei A, Tognotti L (2008) Effect of the heating rate on the devolatilization of

551 biomass residues. Thermochim Acta 472:55-63. https://doi.org/10.1016/j.tca.2008.03.015

552 Brindhadevi K, Anto S, Rene ER, et al (2021) Effect of reaction temperature on the conversion of

553 algal biomass to bio-oil and biochar through pyrolysis and hydrothermal liquefaction. Fuel

554 285:119106. https://doi.org/10.1016/j.fuel.2020.119106

555 Buratti C, Mousavi S, Barbanera M, et al (2016) Thermal behaviour and kinetic study of the olive 556 oil production chain residues and their mixtures during co-combustion. Bioresour Technol 
558 Çepelioğullar Ö, Mutlu İ, Yaman S, Haykiri-Acma H (2018) Activation energy prediction of

559 biomass wastes based on different neural network topologies. Fuel 220:535-545.

$560 \quad$ https://doi.org/10.1016/j.fuel.2018.02.045

561 Ceylan S, Goldfarb JL (2015) Green tide to green fuels: TG-FTIR analysis and kinetic study of

562 Ulva prolifera pyrolysis. Energy Convers Manag 101:263-270.

563 https://doi.org/10.1016/j.enconman.2015.05.029

564 Channiwala SA, Parikh PP (2002) A unified correlation for estimating HHV of solid, liquid and

565 gaseous fuels. Fuel 81:1051-1063. https://doi.org/10.1016/S0016-2361(01)00131-4

566 Das P, Chandramohan VP, Mathimani T, Pugazhendhi A (2021) Science of the Total

567 Environment Recent advances in thermochemical methods for the conversion of algal

$568 \quad$ biomass to energy. Sci Total Environ 766:144608.

569 https://doi.org/10.1016/j.scitotenv.2020.144608

570 de la Torre Maroto M, la Cal Herrera JA, Vilar MM (2020) Dry olive pomace gasification to

571 obtain electrical energy in a downdraft gasifier. WIT Trans Ecol Environ 247:137-144.

$572 \quad$ https://doi.org/10.2495/WM200131

573 Dinc G, Yel E (2018) Self-catalyzing pyrolysis of olive pomace. J Anal Appl Pyrolysis 134:641574 646. https://doi.org/10.1016/j.jaap.2018.08.018

575 Dorado F, Sanchez P, Alcazar-Ruiz A, Sanchez-Silva L (2021) Fast pyrolysis as an alternative to 576 the valorization of olive mill wastes. J Sci Food Agric 101:2650-2658.

577 https://doi.org/10.1002/jsfa.10856

578 Eom IY, Kim JY, Kim TS, et al (2012) Effect of essential inorganic metals on primary thermal

579 degradation of lignocellulosic biomass. Bioresour Technol 104:687-694.

$580 \quad$ https://doi.org/10.1016/j.biortech.2011.10.035 
Fan L, Zhang Y, Liu S, et al (2017) Bio-oil from fast pyrolysis of lignin: Effects of process and upgrading parameters. Bioresour Technol 241:1118-1126. https://doi.org/10.1016/j.biortech.2017.05.129

584 Fernandez A, Palacios C, Echegaray M, et al (2018) Pyrolysis and Combustion of Regional Agro-Industrial Wastes: Thermal Behavior and Kinetic Parameters Comparison. Combust Sci Technol 190:114-135. https://doi.org/10.1080/00102202.2017.1377701

García-Ibañez P, Sánchez M, Cabanillas A (2006) Thermogravimetric analysis of olive-oil residue in air atmosphere. Fuel Process Technol 87:103-107. https://doi.org/10.1016/j.fuproc.2005.08.005 from Hydrothermal Carbonization of Poultry Litter under Different Treatment Conditions.

Ghouma I, Jeguirim M, Guizani C, et al (2017) Pyrolysis of Olive Pomace: Degradation Kinetics,

594 Gaseous Analysis and Char Characterization. Waste and Biomass Valorization 8:16891697. https://doi.org/10.1007/s12649-017-9919-8

Guida MY (2017) Bio-oil and bio-char feedstocks from pyrolysis of olive mill wastes, such as olive mill solid waste and Olive mill wastewater. Indian J Environ Prot 37:632-646

Guida MY, Hannioui A (2016) A review on thermochemical treatment of biomass: Pyrolysis of olive mill wastes in comparison with other types of biomass. Prog Agric Eng Sci 12:1-23.

601 Haddad MEL (2016) Development of Renewable Energies in Tunisia. 1-8

602 İlay R (2020) Short-lived Effects of Olive Pomace Biochar Produced at Different Temperatures 603 on Nitrate (NO3-), Bromide (Br-), Sulfate (SO42-) and Phosphate (PO43-) Leaching from Sandy Loam Soils. Commun Soil Sci Plant Anal 51:2223-2243. 
606 Innangi M, Niro E, D’ Ascoli R, et al (2017) Effects of olive pomace amendment on soil enzyme 607 activities. Appl Soil Ecol 119:242-249. https://doi.org/10.1016/j.apsoil.2017.06.015

608 IOC (2017) Market Newsletter No 121 - November 2017. Int Olive Counc

609 Irfan M, Chen Q, Yue Y, et al (2016) Co-production of biochar, bio-oil and syngas from

610 halophyte grass (Achnatherum splendens L.) under three different pyrolysis temperatures.

611 Bioresour Technol 211:457-463. https://doi.org/10.1016/j.biortech.2016.03.077

612 Khalideh Al bkoor Alrawashdeh, Katarzyna Slopiecka, Abdullah A. Alshorman, et al (2017)

613 Pyrolytic Degradation of Olive Waste Residue (OWR) by TGA: Thermal Decomposition

614 Behavior and Kinetic Study. J Energy Power Eng 11:. https://doi.org/10.17265/1934-

$615 \quad 8975 / 2017.08 .001$

616 Lestander TA, Sandström L, Wiinikka H, et al (2018) Characterization of fast pyrolysis bio-oil

617 properties by near-infrared spectroscopic data. J Anal Appl Pyrolysis 133:9-15.

618 https://doi.org/10.1016/j.jaap.2018.05.009

619 Li C, Hayashi J ichiro, Sun Y, et al (2021) Impact of heating rates on the evolution of function 620 groups of the biochar from lignin pyrolysis. J Anal Appl Pyrolysis 155:.

$621 \quad$ https://doi.org/10.1016/j.jaap.2021.105031

622 López-Linares JC, Gómez-Cruz I, Ruiz E, et al (2020) Production of ethanol from hemicellulosic

623 sugars of exhausted olive pomace by escherichia coli. Processes 8:1-10.

624 https://doi.org/10.3390/PR8050533

625 Mallamaci R, Budriesi R, Clodoveo ML, et al (2021) Olive Tree in Circular Economy as a 626 Source of Secondary Metabolites Active for Human and Animal Health Beyond Oxidative 627 Stress and Inflammation. Molecules 26:. https://doi.org/10.3390/molecules26041072 628 Martín-Lara MA, Blázquez G, Zamora MC, Calero M (2017) Kinetic modelling of torrefaction of 
olive tree pruning. Appl Therm Eng 113:1410-1418.

$630 \quad$ https://doi.org/10.1016/j.applthermaleng.2016.11.147

631 Martín-Lara MA, Ronda A, Blázquez G, et al (2018) Pyrolysis kinetics of the lead-impregnated

632 olive stone by non-isothermal thermogravimetry. Process Saf Environ Prot 113:448-458.

633 https://doi.org/10.1016/j.psep.2017.11.015

634 Mekki H, Anderson M, Benzina M, Ammar E (2008) Valorization of olive mill wastewater by its

635 incorporation in building bricks. J Hazard Mater 158:308-315.

636 https://doi.org/10.1016/j.jhazmat.2008.01.104

637 Miura K (1995) A New and Simple Method to Estimate $\mathrm{f}(\mathrm{E})$ and ko(E) in the Distributed

638 Activation Energy Model from Three Sets of Experimental Data. Energy and Fuels 9:302-

639 307. https://doi.org/10.1021/ef00050a014

640 Nunes LJR, Loureiro LMEF, Sá LCR, Silva HFC (2020) Evaluation of the potential for energy

641 recovery from olive oil industry waste: Thermochemical conversion technologies as fuel

642 improvement methods. Fuel 279:118536. https://doi.org/10.1016/j.fuel.2020.118536

643 Oyebanji JA, Okekunle PO, Lasode OA, Oyedepo SO (2018) Chemical composition of bio-oils

$644 \quad$ produced by fast pyrolysis of two energy biomass. Biofuels 9:479-487.

$645 \quad$ https://doi.org/10.1080/17597269.2017.1284473

646 Pasqualone A, Di Rienzo V, Sabetta W, et al (2016) Chemical and Molecular Characterization of

647 Crude Oil Obtained by Olive-Pomace Recentrifugation. J Chem 2016:.

$648 \quad$ https://doi.org/10.1155/2016/4347207

649 Paz A, Karnaouri A, Templis CC, et al (2020) Valorization of exhausted olive pomace for the

650 production of omega-3 fatty acids by Crypthecodinium cohnii. Waste Manag 118:435-444.

$651 \quad$ https://doi.org/10.1016/j.wasman.2020.09.011

652 Pellera FM, Gidarakos E (2015) Effect of dried olive pomace - Derived biochar on the mobility 
653 of cadmium and nickel in soil. J Environ Chem Eng 3:1163-1176.

654 https://doi.org/10.1016/j.jece.2015.04.005

655 Qi Y, Ge B, Cao Q, et al (2021) Science of the Total Environment Application of sectionalized

656 single-step reaction approach ( SSRA ) and distributed activation energy model ( DAEM )

657 on the pyrolysis kinetics model of upstream oily sludge : Construction procedure and data

$658 \quad$ reproducibility. Sci Total Environ 774:145751.

659 https://doi.org/10.1016/j.scitotenv.2021.145751

660 Raveendran K, Ganesh A (1996) Heating value of biomass and biomass pyrolysis products. Fuel

$661 \quad 75: 1715-1720$. https://doi.org/10.1016/S0016-2361(96)00158-5

662 Ribeiro TB, Oliveira A, Coelho M, et al (2021) Are olive pomace powders a safe source of

663 bioactives and nutrients? J Sci Food Agric 101:1963-1978.

664 https://doi.org/10.1002/jsfa.10812

665 Sfakiotakis S, Vamvuka D (2018) Study of co-pyrolysis of olive kernel with waste biomass using

666 TGA/DTG/MS. Thermochim Acta 670:44-54. https://doi.org/10.1016/j.tca.2018.10.006

667 Sharma A, Pareek V, Zhang D (2015) Biomass pyrolysis - A review of modelling, process

668 parameters and catalytic studies. Renew Sustain Energy Rev 50:1081-1096.

669 https://doi.org/10.1016/j.rser.2015.04.193

670 Sheng C, Azevedo JLT (2005) Estimating the higher heating value of biomass fuels from basic

671 analysis data. Biomass and Bioenergy 28:499-507.

672 https://doi.org/10.1016/j.biombioe.2004.11.008

673 Sizirici B, Fseha YH, Yildiz I, et al (2021) The effect of pyrolysis temperature and feedstock on

674 date palm waste derived biochar to remove single and multi-metals in aqueous solutions.

675 Sustain Environ Res 31:. https://doi.org/10.1186/s42834-021-00083-X

676 Solarte-Toro JC, González-Aguirre JA, Poveda Giraldo JA, Cardona Alzate CA (2021) 

applications and catalytic upgrading. Renew Sustain Energy Rev 136:. https://doi.org/10.1016/j.rser.2020.110376

680 Surahmanto F, Saptoadi H, Sulistyo H, Rohmat TA (2020) Investigation of the slow pyrolysis kinetics of oil palm solid waste by the distributed activation energy model. Biofuels 11:663670. https://doi.org/10.1080/17597269.2017.1387750

683 Timpanaro G, Cosentino S, Danzì C, et al (2021) Prickly pear for biogas production: technical684 economic validation of a biogas power installation in an area with a high prevalence of cacti 685 in Italy. Biofuels, Bioprod Biorefining 1-22. https://doi.org/10.1002/bbb.2190

686 Trabelsi ABH, Ghrib A, Zaafouri K, et al (2017) Hydrogen-Rich Syngas Production from 687 Gasification and Pyrolysis of Solar Dried Sewage Sludge: Experimental and Modeling 688 Investigations. Biomed Res Int 2017:. https://doi.org/10.1155/2017/7831470

689 Tsivas D, Vlyssides A, Vlysidis A (2021) Monitoring of a III-Phase Olive Pomace Composting 690 Process Using the CIELAB Colorimetric Method. Waste and Biomass Valorization. https://doi.org/10.1007/s12649-021-01363-8

692 Vand V (1943) A theory of the irreversible electrical resistance changes of metallic films 693 evaporated in vacuum. Proc Phys Soc 55:222-246. https://doi.org/10.1088/0959$694 \quad 5309 / 55 / 3 / 308$

695 Xiong Z, Wang Y, Syed-Hassan SSA, et al (2018) Effects of heating rate on the evolution of bio696 oil during its pyrolysis. Energy Convers Manag 163:420-427.

697 https://doi.org/10.1016/j.enconman.2018.02.078

698 Yaras A, Demirel B, Akkurt F, Arslanoglu H (2021) Thermal conversion behavior of paper mill 699 sludge: characterization, kinetic, and thermodynamic analyses. Biomass Convers 700 Biorefinery. https://doi.org/10.1007/s13399-020-01232-9 
701 Table 1. Proximate. ultimate. heating value and mineral composition of studied OPW

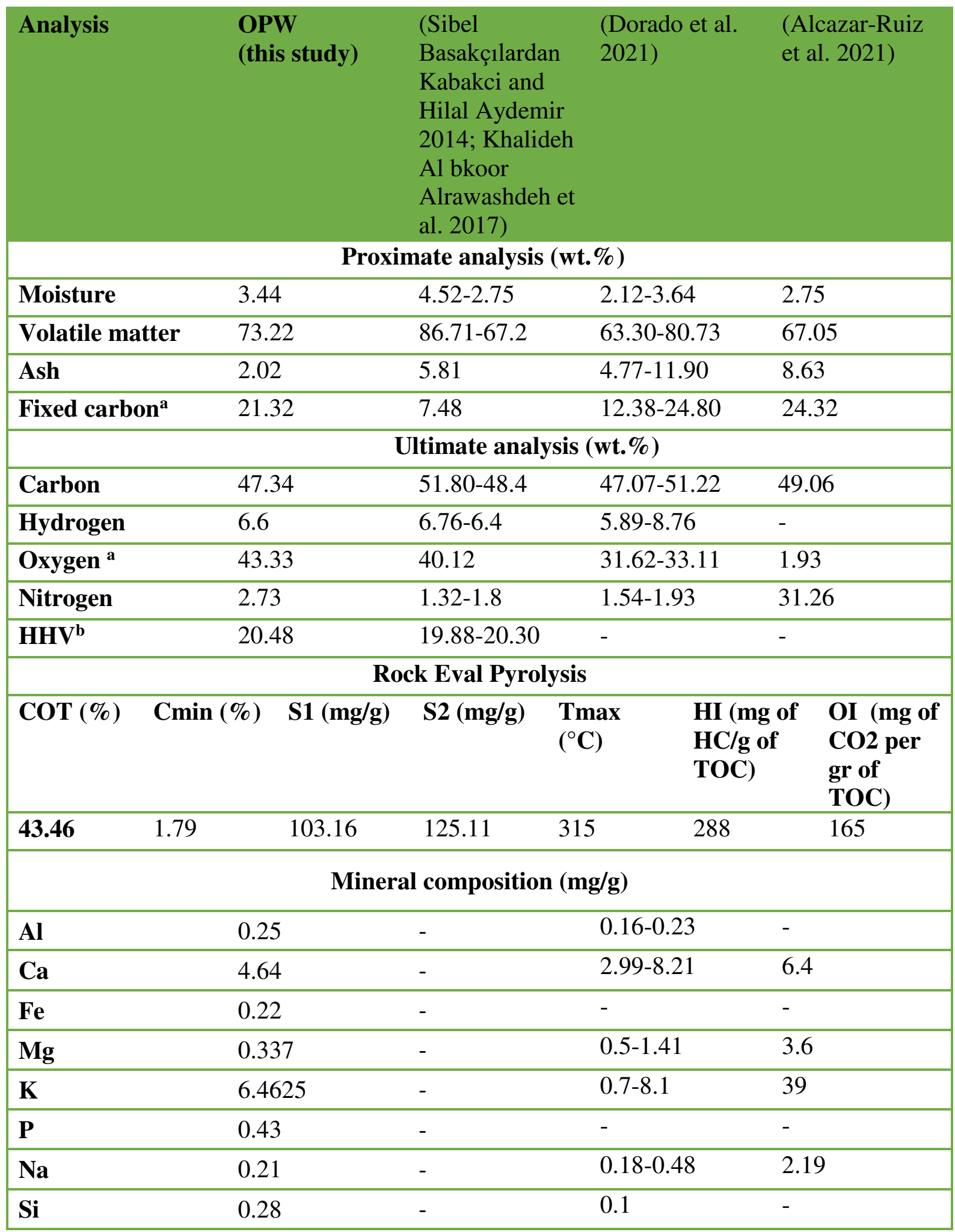

703 a: by difference 
704 b: $\mathrm{HHV}\left(\mathrm{MJ} \mathrm{kg}^{-1}\right)=$ Higher heating value (HHV) calculated by (Shah et al 2012) formula HHV=$7051.3675+0.3137 \mathrm{C}+0.7009 \mathrm{H}+0.0318 \mathrm{O}$

706 
Table.2. Pyrolytic oil (PO) and biochar (BC) CHN-O elemental composition and HHV

\begin{tabular}{|c|c|c|c|c|c|}
\hline Analysis & PO-500-15 & PO-600-15 & PO-700-15 & PO-600-20 & PO-600-25 \\
\hline \multicolumn{6}{|c|}{ Ultimate analysis (wt\%) } \\
\hline Carbon & 50.58 & 57.32 & 51.38 & 66.73 & 67.55 \\
\hline Hydrogen & 8.80 & 6.99 & 9.33 & 9.85 & 8.97 \\
\hline Oxygen $^{a}$ & 39.05 & 34.30 & 37.98 & 22.17 & 22.25 \\
\hline Nitrogen & 1.57 & 1.39 & 1.3 & 1.25 & 1.23 \\
\hline \multicolumn{6}{|c|}{ Heating Value } \\
\hline HHV $^{b}$ & 22.9 & 23.6 & 23.49 & 28.17 & 27.81 \\
\hline LHV & 20.98 & 22.07 & 21.46 & 26.02 & 25.86 \\
\hline \multicolumn{6}{|c|}{ Fuel properties } \\
\hline \multicolumn{3}{|c|}{ Flash point $\left({ }^{\circ} \mathbf{C}\right)$} & \multicolumn{2}{|l|}{ Ash (wt.\%) } & Color \\
\hline \multirow[t]{2}{*}{17.79} & & 44 & 0.02 & & DIL 8 \\
\hline & BC-500-15 & BC-600-15 & BC-700-15 & BC-600-20 & BC-600-25 \\
\hline \multicolumn{6}{|c|}{ Proximate analysis (wt.\%) } \\
\hline Moisture & 8.7 & 6.7 & 6.0 & 9.8 & 7.3 \\
\hline $\begin{array}{l}\text { Volatile } \\
\text { matter }\end{array}$ & 34.8 & 35.2 & 43.9 & 37.8 & 39.7 \\
\hline Ash & 6.7 & 7.2 & 8.0 & 7.9 & 8.5 \\
\hline Fixed carbon $^{a}$ & 58.6 & 57.6 & 48.1 & 54.3 & 51.9 \\
\hline \multicolumn{6}{|c|}{ Ultimate analysis (wt.\%) } \\
\hline $\mathrm{C}$ & 67.80 & 72.54 & 73.38 & 67.80 & 82.03 \\
\hline $\mathbf{H}$ & 3.87 & 2.02 & 2.37 & 2.68 & 3.10 \\
\hline $\mathbf{N}$ & 4.15 & 2.12 & 2.77 & 5.32 & 7.27 \\
\hline $\mathbf{O}$ & 24.18 & 23.32 & 21.48 & 24.20 & 7.60 \\
\hline \multicolumn{6}{|c|}{ High Heating Value (MJ/kg) } \\
\hline HHV & 24.38 & 24.75 & 24.99 & 23.55 & 27.78 \\
\hline LHV & 23.54 & 24.1 & 24.47 & 22.96 & 27.1 \\
\hline $\mathrm{H} / \mathrm{C}$ & 0.79 & 0.38 & 0.45 & 0.55 & 0.53 \\
\hline $\mathbf{O} / \mathrm{C}$ & 0.31 & 0.28 & 0.25 & 0.31 & 0.08 \\
\hline \multicolumn{6}{|c|}{ Mineral composition (mg/g) } \\
\hline $\mathrm{Ca}$ & $\mathrm{Fe}$ & $\mathrm{Mg}$ & $\mathrm{P}$ & $\mathrm{Na}$ & $\mathrm{Si}$ \\
\hline 8.43 & 0.43 & 0.47 & 0.64 & 0.29 & 0.56 \\
\hline
\end{tabular}


b: HHV= Higher heating value (HHV) calculated by (Shah et al 2012) formula

711 $[\mathrm{HHV}=-1.3675+0.3137 * \mathrm{C}+0.7009 * \mathrm{H}+0.0318 * \mathrm{O}]$

712

Table 3. Previous kinetics model results of olive by-products and other biomasses

\begin{tabular}{|c|c|c|c|c|c|c|c|}
\hline Raw material & $\begin{array}{l}\text { Applied } \\
\text { Model }\end{array}$ & Heating rate & \multicolumn{4}{|c|}{ Activation energy } & References \\
\hline \multirow[t]{2}{*}{ Olive pits } & DAEM & \multirow{2}{*}{$\begin{array}{l}5,10 \text { and } 15 \\
\mathrm{~K} / \mathrm{min}\end{array}$} & \multicolumn{4}{|c|}{110.18} & \multirow{2}{*}{$\begin{array}{l}\text { (Fernandez et } \\
\text { al.. 2018) }\end{array}$} \\
\hline & FWO & & \multicolumn{4}{|c|}{113.8} & \\
\hline \multirow[t]{2}{*}{ Olive Pomace } & \multirow[t]{2}{*}{ KAS } & \multirow{2}{*}{$\begin{array}{l}5,10,15,20 \\
\text { and } \\
25^{\circ} \mathrm{C} / \mathrm{min}\end{array}$} & E1 & E2 & \multicolumn{2}{|c|}{ E3 } & \multirow{2}{*}{$\begin{array}{l}\text { (Ghouma et } \\
\text { al.. 2017) }\end{array}$} \\
\hline & & & $\begin{array}{c}102.49- \\
104.38\end{array}$ & $\begin{array}{l}283.43- \\
246.79\end{array}$ & \multicolumn{2}{|c|}{$\begin{array}{l}35.77- \\
43.84\end{array}$} & \\
\hline $\begin{array}{ll}\text { Olive } & \text { tree } \\
\text { prunning }\end{array}$ & \multirow[t]{3}{*}{ FWO } & \multirow[t]{3}{*}{$\begin{array}{l}2.5 .10 \text { and } \\
15 \mathrm{~K} / \mathrm{min}\end{array}$} & \multicolumn{4}{|c|}{$26.57-185.7$} & \multirow{3}{*}{$\begin{array}{l}\text { (Khalideh Al } \\
\text { bkoor } \\
\text { Alrawashdeh } \\
\text { et al.. 2017) }\end{array}$} \\
\hline Olive pomace & & & \multirow{2}{*}{\multicolumn{4}{|c|}{$\frac{116.4-202.99}{26.58-214.94}$}} & \\
\hline Olive kernel & & & & & & & \\
\hline & \multirow{4}{*}{$\begin{array}{l}\text { Modified } \\
\text { IPR } \\
\text { model }\end{array}$} & \multirow{4}{*}{$\begin{array}{l}5 . \quad 10 . \quad 20 . \\
30.40 \text { and } \\
50^{\circ} \mathrm{C} / \mathrm{min}\end{array}$} & E1 & E2 & E3 & $\mathrm{E} 4$ & \multirow{4}{*}{$\begin{array}{l}\text { (Sfakiotakis } \\
\text { and Vamvuka. } \\
\text { 2018) }\end{array}$} \\
\hline Olive kernel & & & 185 & 132.9 & 46.2 & 47.9 & \\
\hline Sewage Sludge & & & 134 & 133.7 & 33.9 & 44.8 & \\
\hline \multirow[t]{2}{*}{$\begin{array}{l}\text { Municipal } \\
\text { solid waste }\end{array}$} & & & 92 & 152.5 & 31.8 & - & \\
\hline & \multirow{3}{*}{$\begin{array}{l}\text { Fr, } \\
\text { FWO } \\
\text { and KAS }\end{array}$} & \multirow{3}{*}{$\begin{array}{l}5 . \quad 10.20 \\
\text { and } \\
50^{\circ} \mathrm{C} / \mathrm{min}\end{array}$} & $\mathrm{Fr}$ & FWO & \multirow{2}{*}{\multicolumn{2}{|c|}{ KAS }} & \multirow{3}{*}{$\begin{array}{l}\text { (Çepelioğullar } \\
\text { et al.. 2018) }\end{array}$} \\
\hline $\begin{array}{ll}\text { Olive } & \text { oil } \\
\text { residue } & \end{array}$ & & & 187.2 & 185.9 & & & \\
\hline $\begin{array}{l}\text { Lignocellulosi } \\
\text { c forest residue }\end{array}$ & & & 158.9 & 155.2 & \multicolumn{2}{|c|}{153.4} & \\
\hline & \multirow{4}{*}{$\begin{array}{l}\text { Fr, FWO } \\
\text { and KAS }\end{array}$} & \multirow{4}{*}{$\begin{array}{lrr}5 . & 10 . & 15 . \\
20 . & 40 . & 60 \\
\text { and } & 100 \\
\mathrm{~K} / \mathrm{min} & \end{array}$} & Fr & FWO & \multicolumn{2}{|c|}{ KAS } & \multirow{4}{*}{$\begin{array}{l}\text { (Biagini et al.. } \\
\text { 2008) }\end{array}$} \\
\hline Rice husks & & & 135.5 & 128.1 & \multicolumn{2}{|c|}{112.5} & \\
\hline Olive cake & & & 112.1 & 117.8 & \multirow{2}{*}{\multicolumn{2}{|c|}{$\frac{103.2}{65.3}$}} & \\
\hline Caco shell & & & 127.7 & 129.6 & & & \\
\hline
\end{tabular}


723 Table 4. Fitted equations and correlation coefficients with resulting activation energies and 724 frequency factors for Olive Pomace pyrolysis obtained by DAEM

\begin{tabular}{|l|l|l|l|l|}
\hline $\mathbf{x}$ & Equation & $\mathbf{R}^{2}$ & $\mathbf{E}$ & $\mathbf{k 0}$ \\
\hline $\mathbf{0 . 2}$ & $\mathrm{y}=-18004 \mathrm{x}+22.853$ & 0.9984 & 149.7 & $8.3 \mathrm{E}+13$ \\
\hline $\mathbf{0 . 2 5}$ & $\mathrm{y}=-18227 \mathrm{x}+23$ & 0.9982 & 151.5 & $9.7 \mathrm{E}+13$ \\
\hline $\mathbf{0 . 3}$ & $\mathrm{y}=-18216 \mathrm{x}+22.717$ & 0.9964 & 151.4 & $7.3 \mathrm{E}+13$ \\
\hline $\mathbf{0 . 3 5}$ & $\mathrm{y}=-18010 \mathrm{x}+22.085$ & 0.9939 & 149.7 & $3.8 \mathrm{E}+13$ \\
\hline $\mathbf{0 . 4}$ & $\mathrm{y}=-17633 \mathrm{x}+21.133$ & 0.9929 & 146.6 & $1.5 \mathrm{E}+13$ \\
\hline $\mathbf{0 . 4 5}$ & $\mathrm{y}=-16833 \mathrm{x}+19.452$ & 0.9814 & 139.9 & $2.6 \mathrm{E}+12$ \\
\hline $\mathbf{0 . 5}$ & $\mathrm{y}=-15960 \mathrm{x}+17.642$ & 0.9691 & 132.7 & $4.0 \mathrm{E}+11$ \\
\hline $\mathbf{0 . 5 5}$ & $\mathrm{y}=-15147 \mathrm{x}+15.96$ & 0.9606 & 125.9 & $7.0 \mathrm{E}+10$ \\
\hline $\mathbf{0 . 6}$ & $\mathrm{y}=-14630 \mathrm{x}+14.807$ & 0.9504 & 121.6 & $2.1 \mathrm{E}+10$ \\
\hline $\mathbf{0 . 6 5}$ & $\mathrm{y}=-14634 \mathrm{x}+14.567$ & 0.9489 & 121.7 & $1.7 \mathrm{E}+10$ \\
\hline $\mathbf{0 . 7}$ & $\mathrm{y}=-14998 \mathrm{x}+14.946$ & 0.9488 & 124.7 & $2.6 \mathrm{E}+10$ \\
\hline $\mathbf{0 . 7 5}$ & $\mathrm{y}=-16086 \mathrm{x}+16.539$ & 0.9537 & 133.7 & $1.3 \mathrm{E}+11$ \\
\hline $\mathbf{0 . 8}$ & $\mathrm{y}=-17597 \mathrm{x}+18.814$ & 0.9665 & 146.3 & $1.4 \mathrm{E}+12$ \\
\hline
\end{tabular}




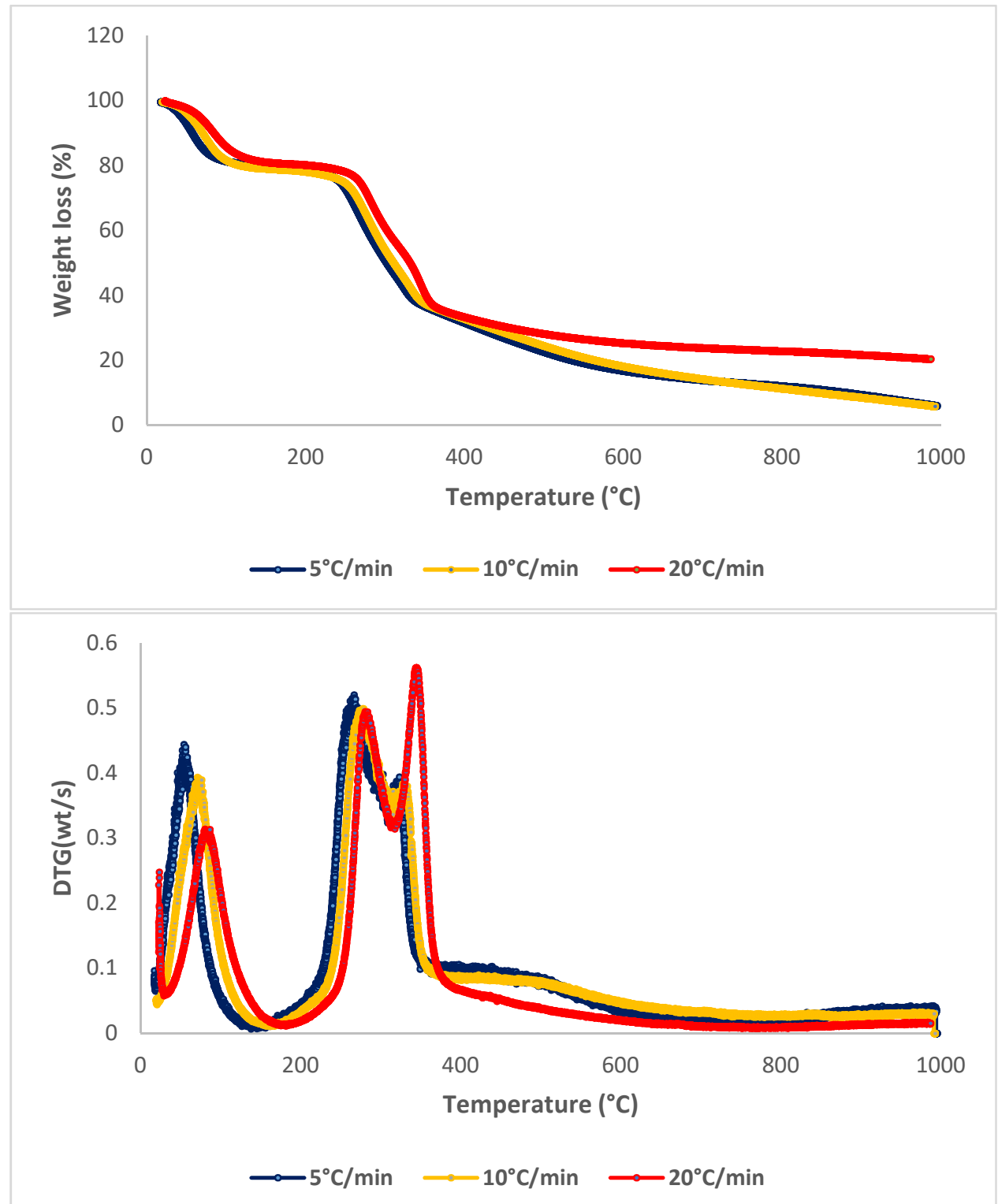

Figure 1 : TGA/DTG curves of $O P W$ at different heating rate 5,10 and $20^{\circ} \mathrm{C} / \mathrm{min}$ 


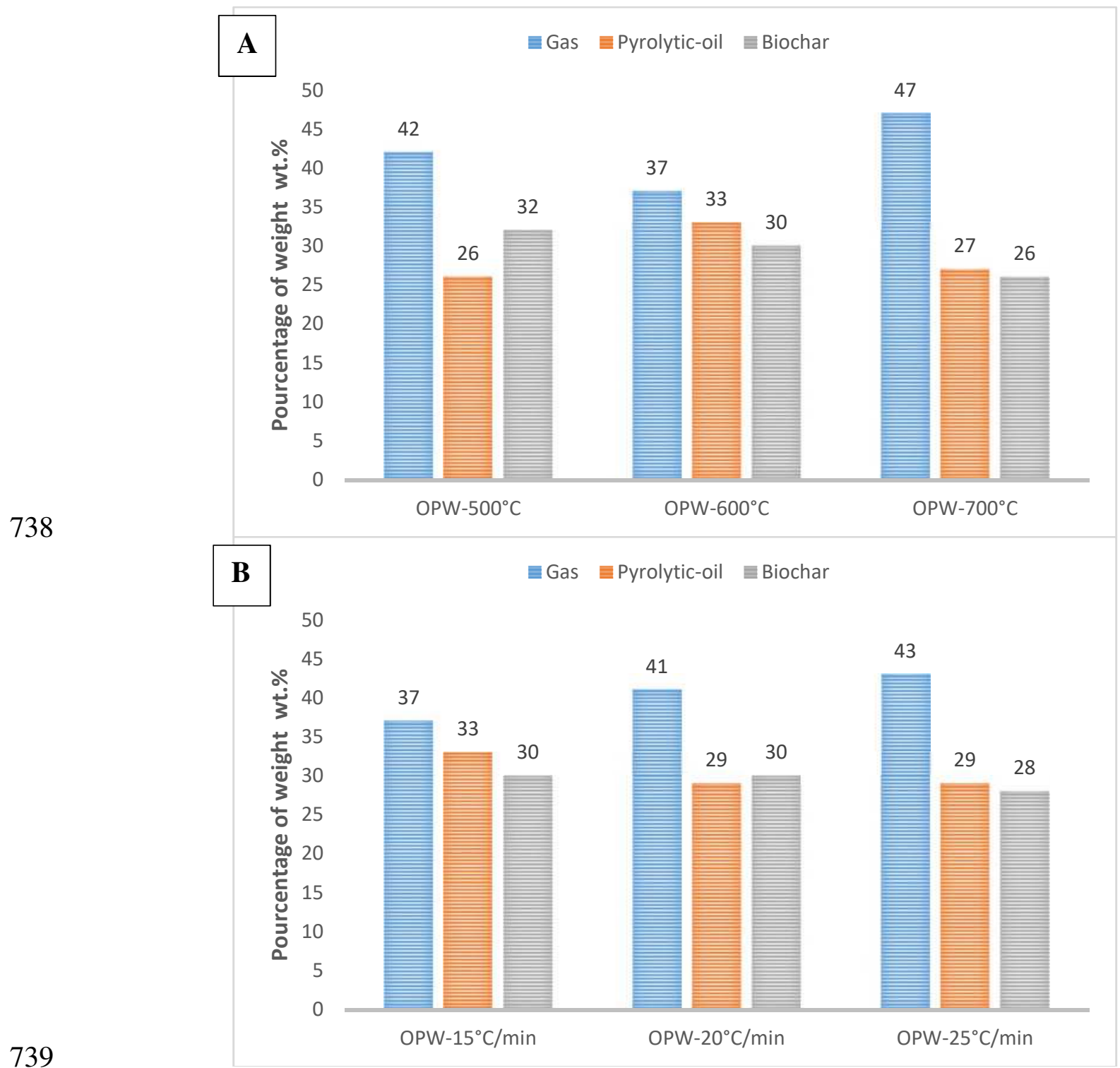

740 Figure 2 : Pyrolytic products yields variation (A) with final pyrolysis temperature and (B) 741 with heating rate

742 

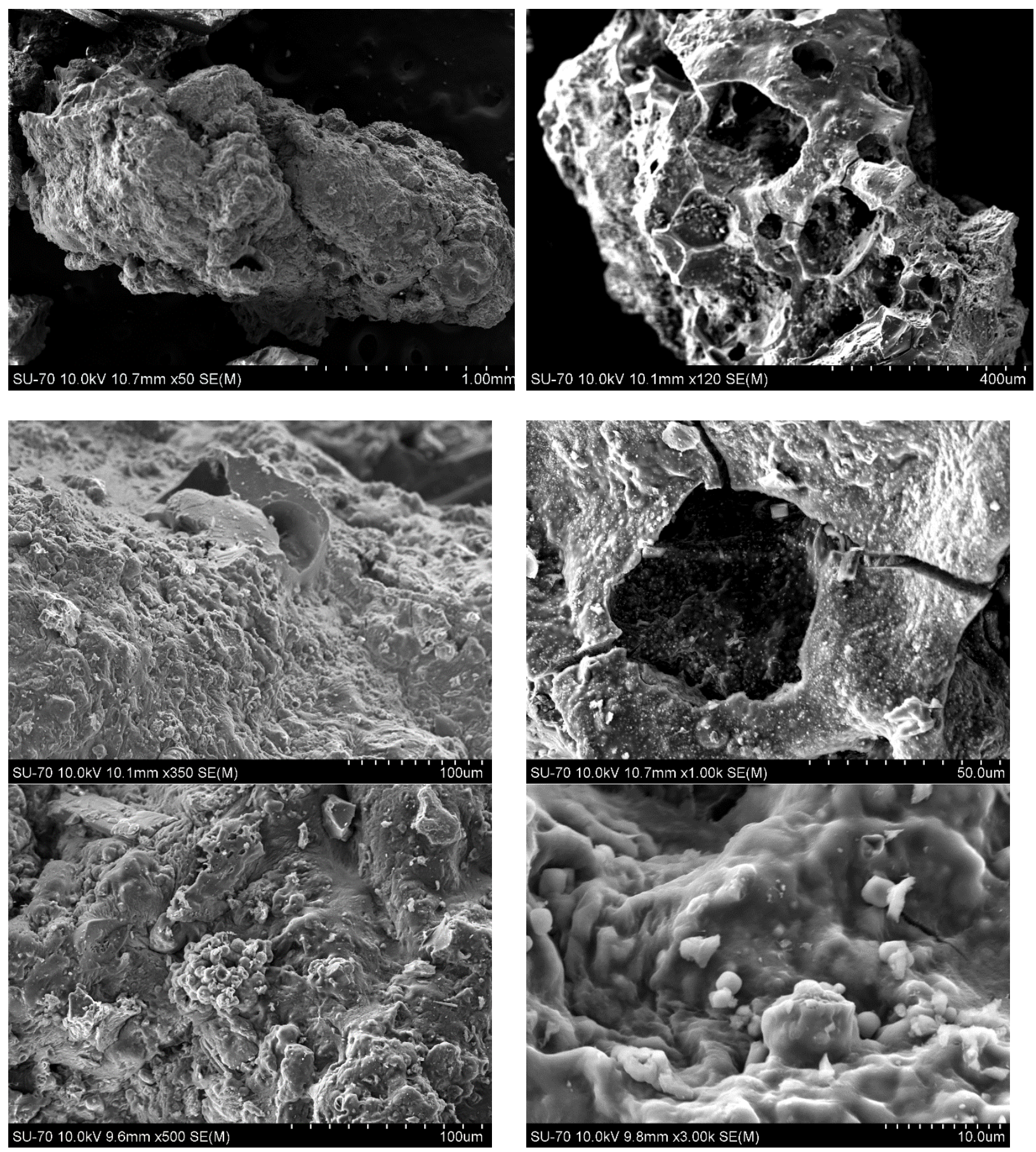

Figure 3: SEM of biochar produced at $600^{\circ} \mathrm{C}$

745

746

747 


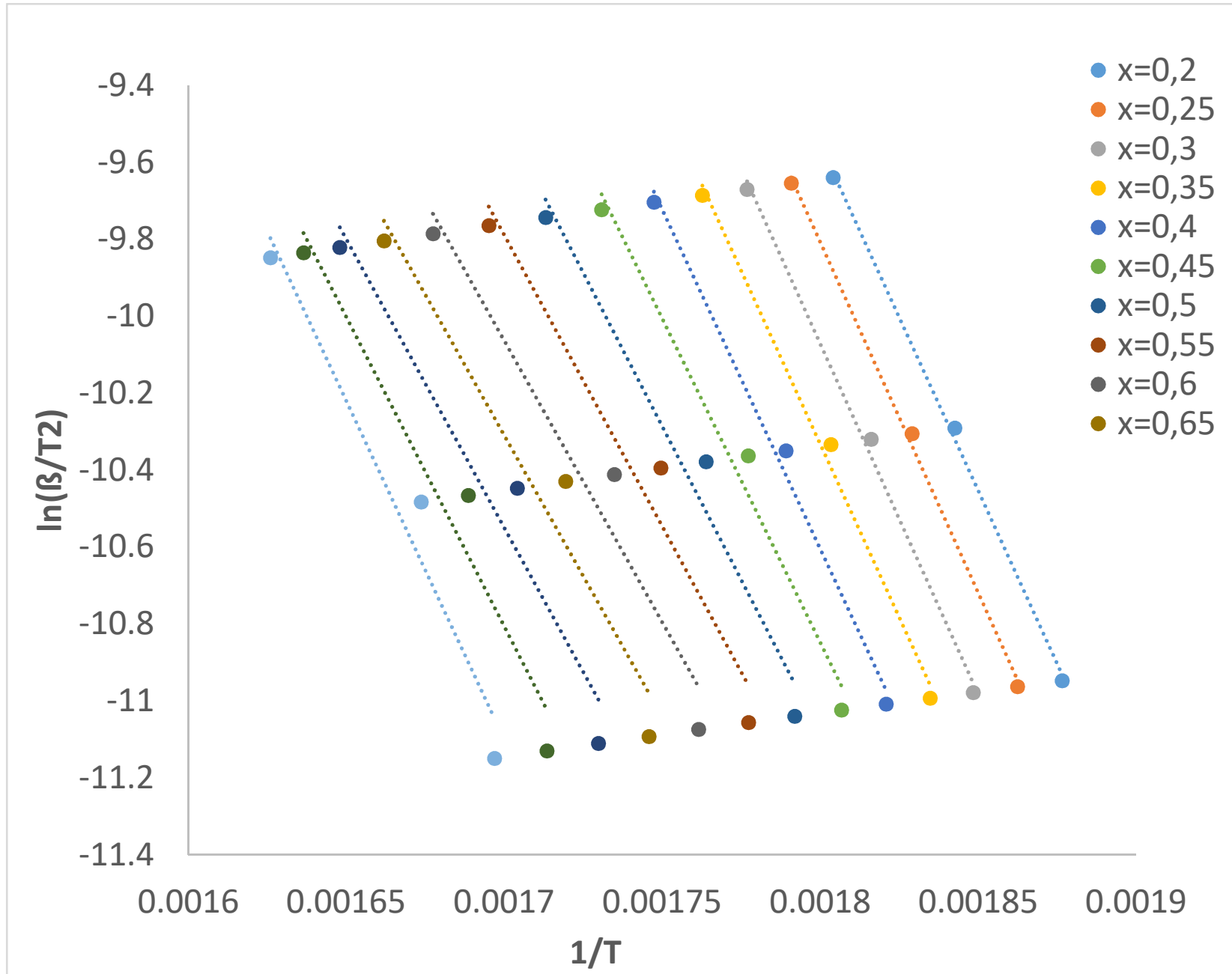

750

Figure 4: Isoconversional plot for determination of activation energy of pyrolysis of olive pomace via the distributed activation energy model. 


\section{Supplementary Files}

This is a list of supplementary files associated with this preprint. Click to download.

- 04SuplementaryInformation.docx

- 0Graphicalabstrat.docx 